\title{
Measuring Land Subsidence from Space
}

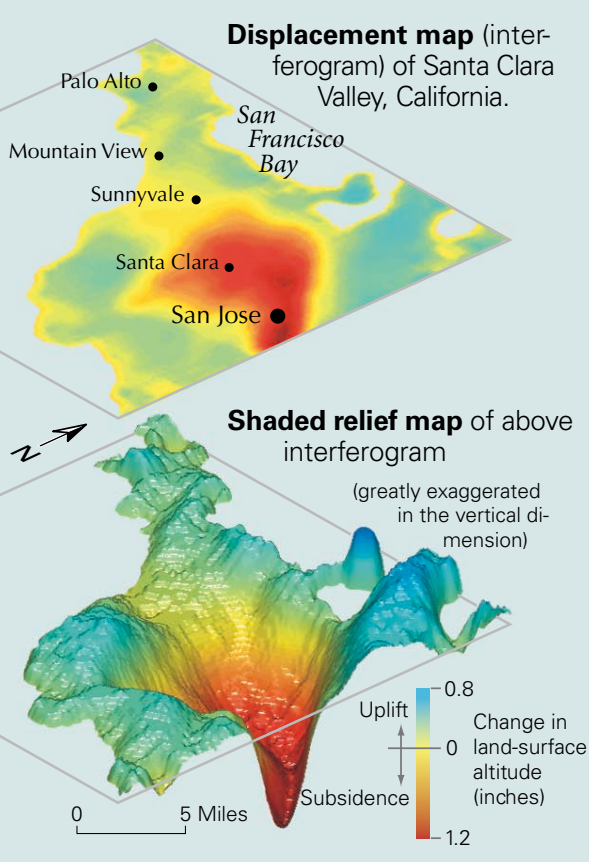

Interferogram of Santa Clara Valley shows patterns of subsidence and some uplift occurring over 7 months in 1997, from January 4 to August 2. A central subsidence zone, (red) the result of seasonal ground-water pumping, is fully recoverable.
Land subsidence is a gradual settling or sudden sinking of the Earth's surface owing to subsurface movement of earth materials. Subsidence in the United States has directly affected more than 17,000 square miles in 45 states, and associated annual costs are estimated to be approximately $\$ 125$ million. The principal causes of subsidence are aquifer-system compaction, drainage of organic soils, underground mining, hydrocompaction, natural compaction, sinkholes, and thawing permafrost (National Research Council, 1991).

A powerful new mapping tool (InSAR) is a critical element in the assessment and mitigation of subsidence. InSAR is capable of remotely sensing small changes in land surface elevation at an unprecedented level of spatial detail. The new displacement maps enhance our capabilities to monitor and manage subsidence caused by the compaction of susceptible aquifer systems, and reveal new insights into the controlling physical processes.
I nterferometric Synthetic Aperture Radar (InSAR) is a powerful new tool that uses radar signals to measure deformation of the Earth's crust at an unprecedented level of spatial detail and high degree of measurement resolu- tion. InSAR is now being used by the USGS and others to map and monitor subsidence caused by the compaction of aquifer systems. Geophysical applications of radar interferometry take advantage of the phase component of reflected radar signals to measure apparent changes in the range distance of the land surface (Gabriel and others, 1989; Massonnet and Feigl, 1998). Ordinary radar on a typical Earth-orbiting satellite has a very poor ground resolution of about 3 to 4 miles because of the restricted size of the antenna on the satellite. Synthetic Aperture Radar (SAR) takes advantage of the motion of the spacecraft along its orbital track to mathematically reconstruct (synthesize) an operationally larger antenna and yield high-spatial-resolution imaging capability on the order of hundreds of feet. The size of a picture element (pixel) on a typical SAR image made from satellite-borne radar may be as small as tens of thousands of square feet, depending how the image is processed.

For landscapes with more or less stable radar reflectors (such as buildings or other engineered structures, or undisturbed rocks and ground surfaces) over a period of time, it is possible to make highprecision measurements of the change in the position of the reflectors by subtracting or "interfering" two radar scans made of the same area at different times. This is the principle behind InSAR.

Under ideal conditions, it is possible to resolve changes in elevation on the order of 0.2 to 0.4 inches ( 5 to $10 \mathrm{~mm}$ ) at

\footnotetext{
Radar is an active sensor, transmitting a signal of electromagnetic energy. Satelliteborne radar using one antenna transmits a pulsed train of microwaves. The waves reflect off the ground surface, and echoes are received by the moving antenna, producing a recorded image of the scanned ground that is continuous along the track of the satellite and about 60 miles wide.

The restricted size of the satellite antenna limits the spatial resolution to 3 to 4 miles on the ground. Synthetic Aperture Radar (SAR) imaging "synthesizes" an effectively larger antenna (about 3 miles long) with a spatial resolution on the order of 16 feet by pulsing the microwaves every 16 feet of satellite travel.

The 3- to 4-mile-wide footprints overlapped at 16-foot intervals along the ground track are processed through a technique similar to medical $x$-ray imaging. Averaging of the signal is done to improve signal coherence, and the actual spatial resolution is typically on the order of 260 feet or better.

Interferograms are made by differencing successive SAR images taken from the same orbital position but at different times. Under favorable radiometric conditions 0.4-inch to 0.2 -inch resolution is possible in the line-of-sight (range) of the radar.
}

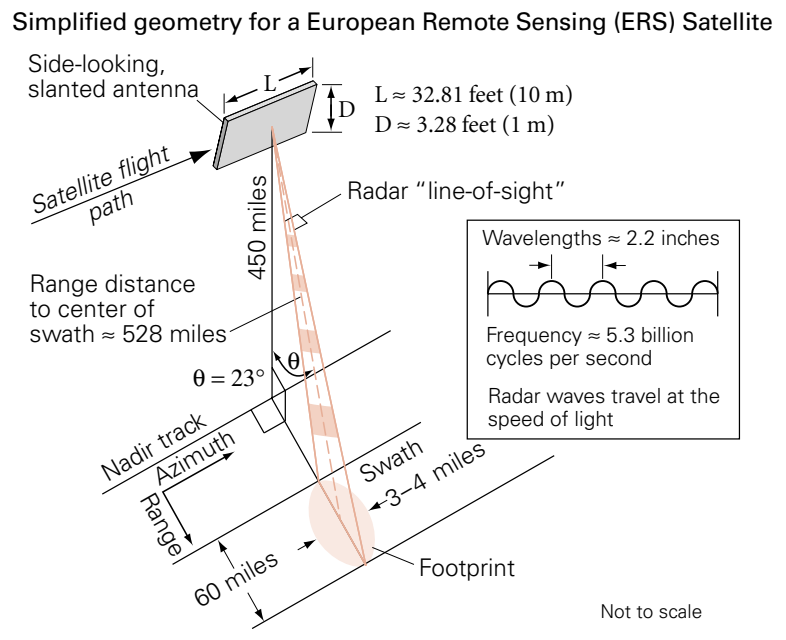


the scale of one pixel. Interferograms, formed from patterns of interference between the phase components of two radar scans made from nearly the same antenna position (viewing angle) but at different times, have demonstrated dramatic potential for high-density spatial mapping of ground-surface displacements associated with tectonic (Massonnet and others, 1993; Zebker and others, 1994) and volcanic strains (Massonnet and others, 1995; Rosen and others, 1996; Wicks and others, 1998). InSAR has also recently been used to map localized crustal deformation and land subsidence associated with geothermal fields in Imperial Valley, California (Massonnet and others, 1997), Long Valley, California (W. Thatcher, USGS, written communication, 1997), and Iceland (Vadon and Sigmundsson, 1997), and with oil and gas fields in the Central Valley, California (Fielding and others, 1998). InSAR has also been used to map regional-scale land subsidence caused by aquifer-system compaction in the Antelope Valley, California (Galloway and others, 1998), Las Vegas Valley, Nevada (Amelung and others, 1999), and Santa Clara Valley, California (Ikehara and others, 1998).

\section{InSAR maps subsidence at high spa- tial detail and reveals new insights}

In the Antelope Valley, Mojave Desert, California, an interferogram for the period October 20, 1993 to December 22, 1995

Different methods of measuring land subsidence

\begin{tabular}{|c|c|c|c|c|}
\hline METHOD & $\begin{array}{l}\text { Component } \\
\text { displacement }\end{array}$ & $\begin{array}{l}\text { Resolution }{ }^{1} \\
\text { (millimeters) }\end{array}$ & $\begin{array}{l}\text { Spatial density }{ }^{2} \\
\text { (samples/survey) }\end{array}$ & $\begin{array}{c}\text { Spatial scale } \\
\text { (elements) }\end{array}$ \\
\hline Spirit level & vertical & $0.1-1$ & $10-100$ & line-network \\
\hline Geodimeter & horizontal & 1 & $10-100$ & line-network \\
\hline $\begin{array}{l}\text { Borehole } \\
\text { extensometer }\end{array}$ & vertical & $0.01-0.1$ & $1-3$ & point \\
\hline \multicolumn{5}{|l|}{$\begin{array}{l}\text { Horizontal } \\
\text { extensometer: }\end{array}$} \\
\hline Tape & horizontal & 0.3 & $1-10$ & line-array \\
\hline Invar wire & horizontal & 0.0001 & 1 & line \\
\hline Quartz tube & horizontal & 0.00001 & 1 & line \\
\hline GPS & $\begin{array}{l}\text { vertical } \\
\text { horizontal }\end{array}$ & $\begin{array}{r}20 \\
5\end{array}$ & $10-100$ & network \\
\hline InSAR & range & $5-10$ & $\begin{array}{l}100,000- \\
10,000,000\end{array}$ & map pixel $^{3}$ \\
\hline
\end{tabular}

${ }^{1}$ Measurement resolution attainable under optimum conditions. Values are given in metric units to conform with standard geodetic guidelines. (One inch is equal to 25.4 millimeters and 1 foot is equal to 304.8 millimeters.)

${ }^{2}$ Number of measurements generally attainable under good conditions to define the spatial extent of land subsidence at the scale of the survey.

${ }^{3} \mathrm{~A}$ pixel on an InSAR displacement map is typically 40 to 80 meters square on the ground.

revealed up to 2 inches of additional subsidence in areas previously affected by as much as 6 feet of subsidence between 1930-92 (Galloway and others, 1998). The regions of maximum subsidence detected during the 26-month period correlated well with declining ground-water levels. In another part of Antelope Valley formerly affected by ground-water depletion and subsidence, about 1 inch of subsidence was detected on the interferogram despite the fact that ground-water levels had been recover- ing since 1990. This suggests residual (time-delayed) compaction due to the presence of thick aquitards. An independent computer simulation of aquifer-system compaction for the same period as the interferogram showed that though the general patterns of subsidence detected by the interferogram could be explained by the simulation, the detailed spatial variations in the interferogram could not. These results highlight the potential use of spatially detailed InSAR measurements to pro-

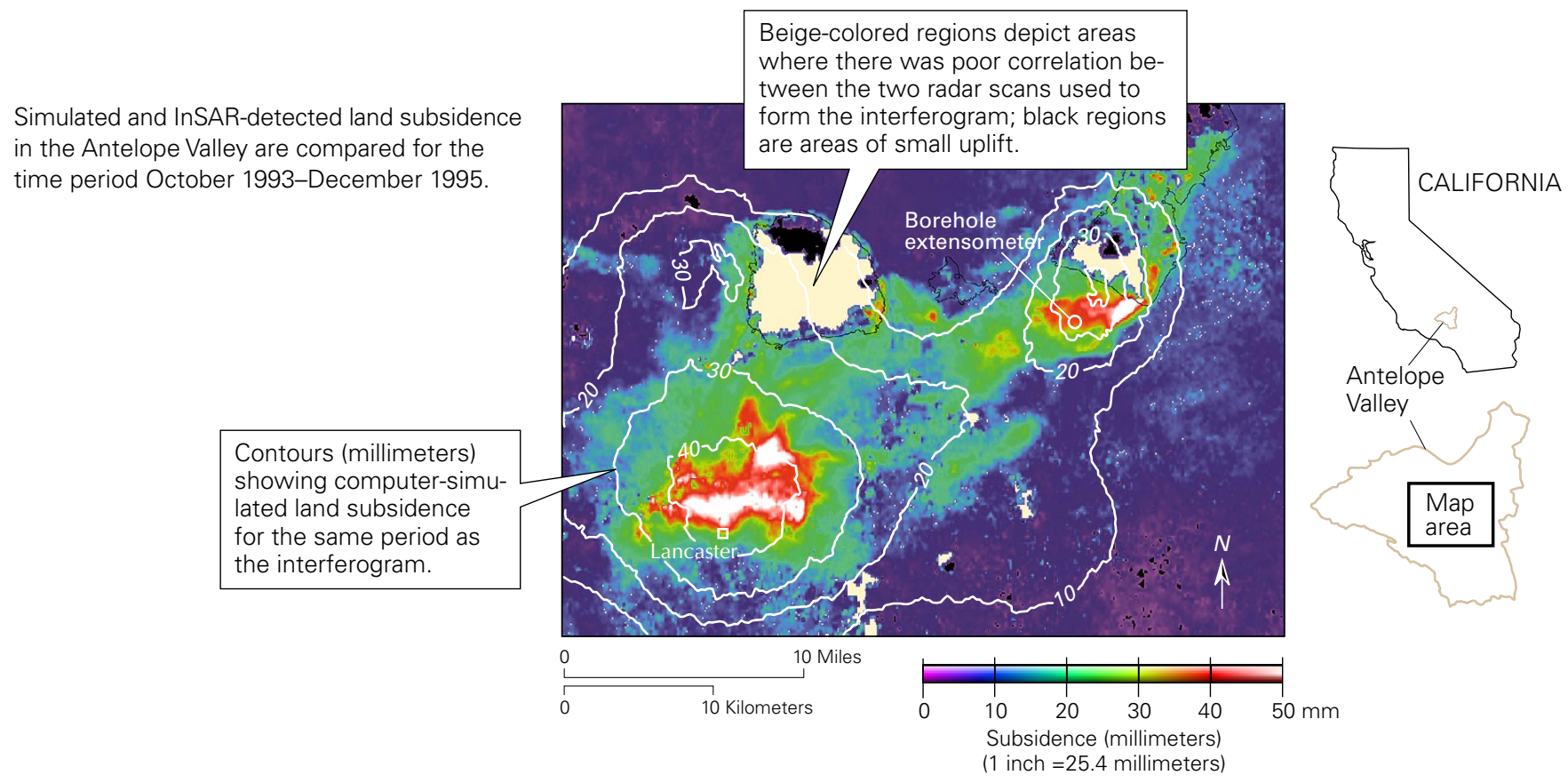


This InSAR-derived surface-deformation map shows subsidence in the Las Vegas Valley between April 1992 and December 1997. It was obtained by summing three timesequential interferograms. The subsidence is caused by aquifer-system compaction and controlled in part by the surface faults, which have also been the focal point of earth-fissure formation (Amelung and others, 1999).

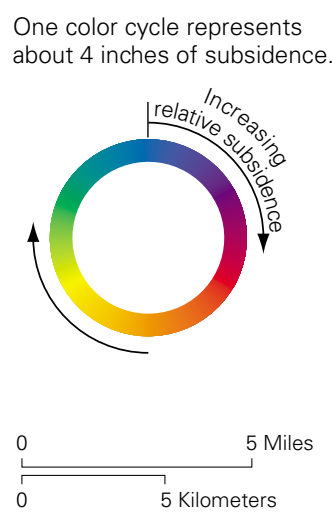

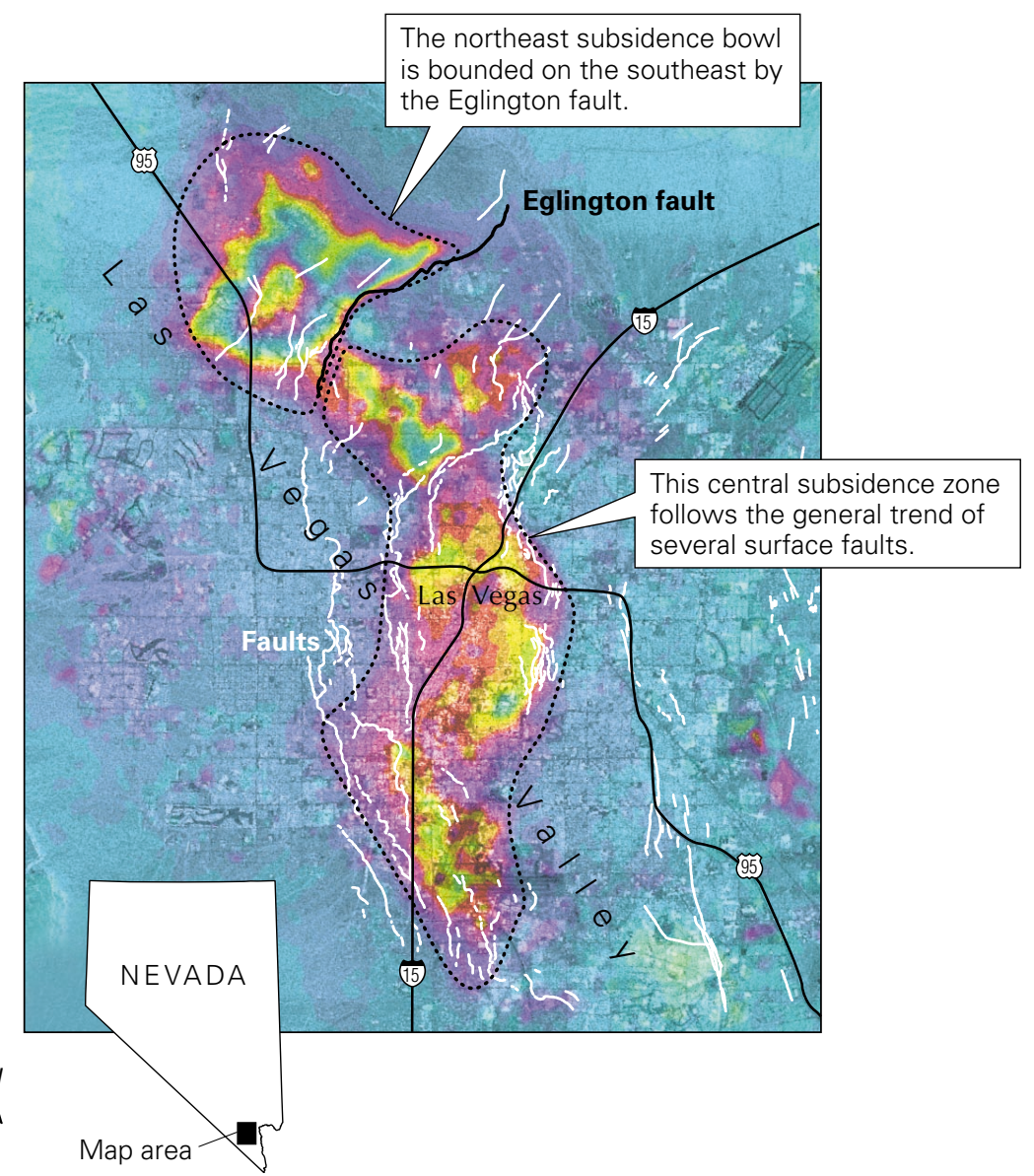

sure changes and creating ground-waterlevel differences across the faults.

In Santa Clara Valley, California, subsidence has been arrested by importation of surface water and careful management of the aquifer system. However, the potential for renewed subsidence is a concern for the Santa Clara Valley Water District. One of the District's objectives is to limit ground-water extractions that would cause inelastic (irreversible) compaction of the valley's aquifer system. Seasonal and longer-term elevation changes were measured from successive satellite radar passes during 1992-1997. The longer-term ( $\sim 5$ year) interferogram indicates no change for most of the southwestern Santa Clara Valley and land-surface uplift of up to about 1 inch in the northern and eastern parts of the valley. This uplift is correlated to the recovery of ground-water levels that has been occurring for several years as a result of reduced pumpage and increased recharge. In contrast, the seasonal (8 month) interferogram reveals a large region in San Jose undergoing elastic deformation caused by seasonal groundwater-level fluctuations. The eastern

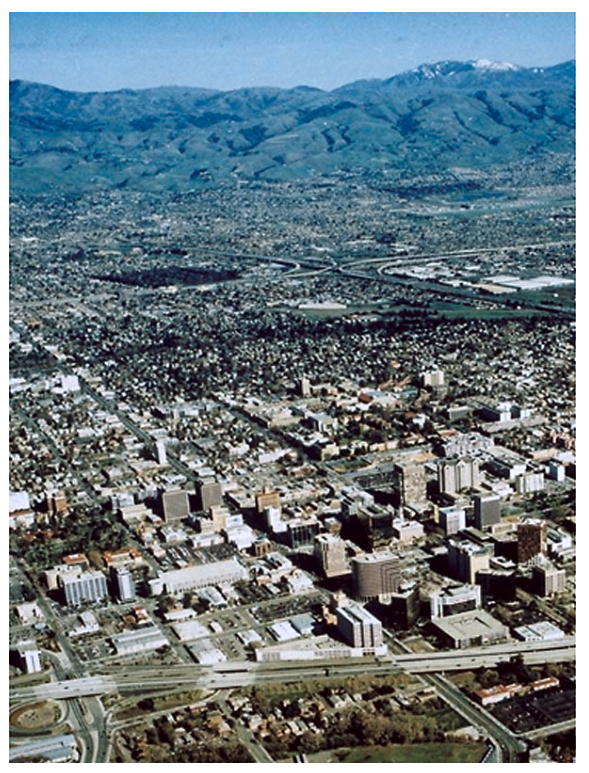

San Jose and surrounding communities sprawl across Santa Clara Valley ("Silicon Valley") where a maximum detected subsidence of 14 feet occurred in downtown San Jose between 1910 and 1995. Since the late 1980s subsidence has been arrested due largely to the importation of surface water. Urban settings are good candidates for radar interferometry because the structures make good radar reflectors. solidation properties, or they may act as barriers to ground-water flow, impeding the horizontal propagation of fluid-pres- 
Between January and August 1997 seasonal, recoverable subsidence occurred due to seasonal ground-water-level declines.

Between 1992 and 1997 some uplift occurred due to recovering ground-water levels.

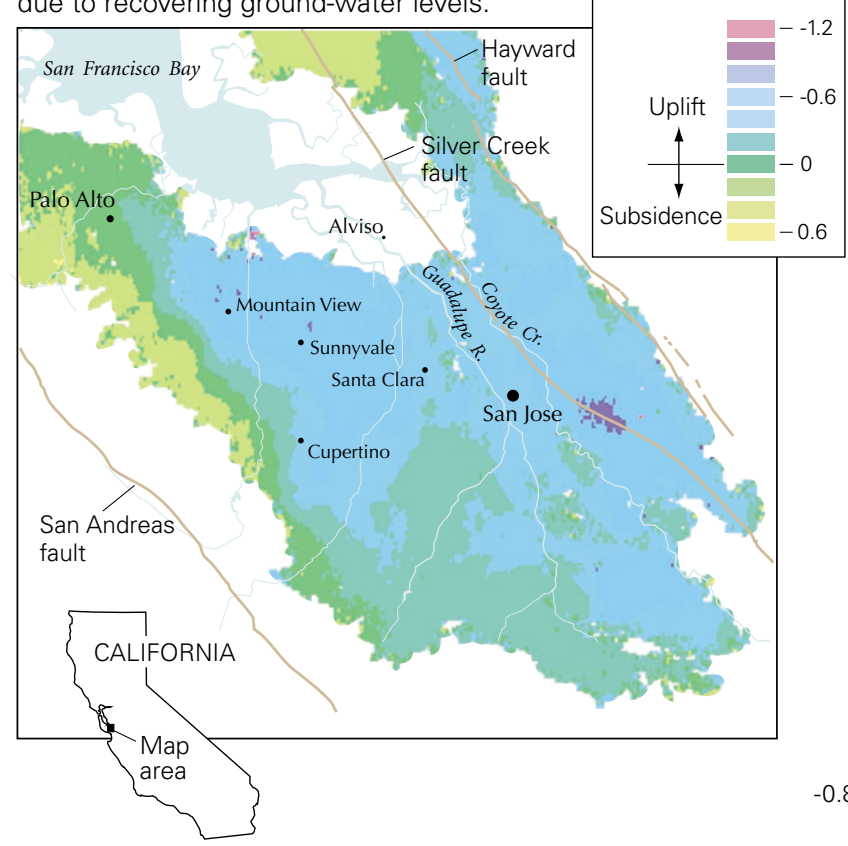

Subsidence patterns during this period are similar to historical subsidence patterns (1934-1967).

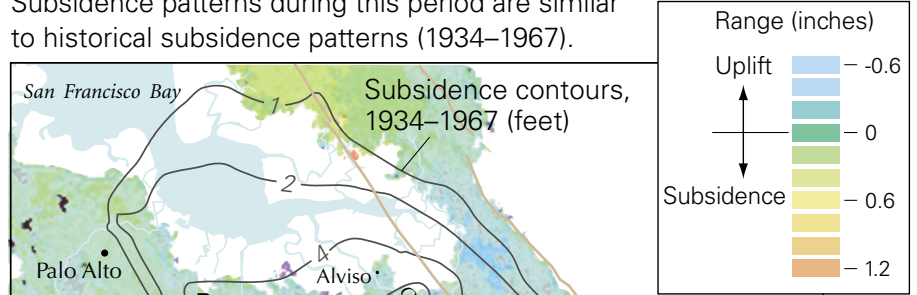

extent of this deformation appears to be aligned with a Quaternary fault, the Silver Creek fault, several miles west of and roughly parallel to the tectonically active Hayward Fault. The InSARderived displacements are consistent with historical patterns of subsidence and vertical displacements measured in deepseated borehole extensometers in Sunnyvale and San Jose.

\section{-D.L. Galloway, D.R. Jones, and S.E. Ingebritsen}

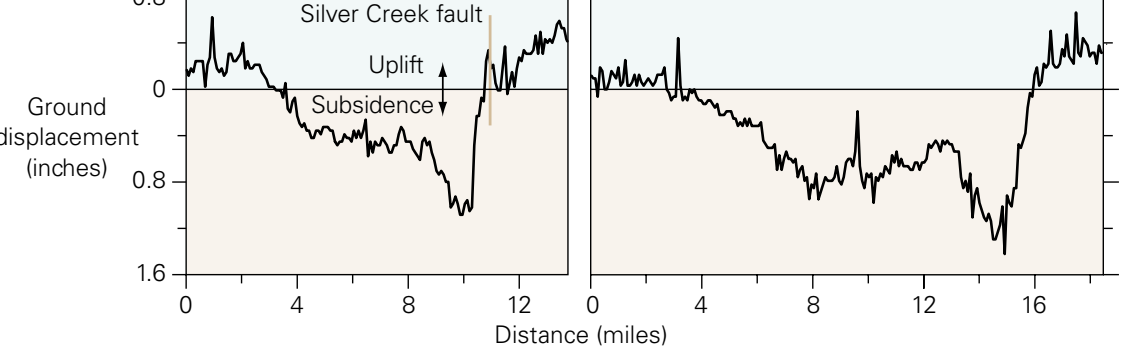

Profiles of ground displacements sampled from cross sections A-A' and B-B' on the seasonal interferogram reveal steep displacement gradients near the trace of an inferred northwesterly extension of the buried Silver Creek fault zone. Recent geophysical surveys (seismic reflection/refraction), undertaken as a result of the interferogram, confirm the presence of buried faults at this boundary (R. Catchings, USGS, written communication, 2000).

(Radar data used to produce the interferograms shown in Agency, distributed through Eurimage Corporation and Radarsat International for purposes of research and development.) this Fact Sheet were obtained from the European Space

\section{REFERENCES}

Amelung, F., Galloway, D.L., Bell, J.W., Zebker, H.A., and Laczniak, R.J., 1999, Sensing the ups and downs of Las Vegas-InSAR reveals structural control of land subsidence and aquifer-system deformation: Geology, v. 27, p. 483-486.

Fielding, E.J., Blom, R.G., and Goldstein, R.M., 1998 Rapid subsidence over oil fields measured by SAR interferometry: Geophysical Research Letters, v. 27, p. 3,215-3,218.

Gabriel, A.K., Goldstein, R.M., and Zebker, H.A., 1989, Mapping small elevation changes over large areas-Differential radar interferometry: Journal of Geophysical Research, v. 94, p. 9,183-9,191.

Galloway, D.L., Hudnut, K.W., Ingebritsen, S.E., Phillips, S.P., Peltzer, G., Rogez, F., and Rosen, P.A., 1998, Detection of aquifer system compaction and land subsidence using interferometric synthetic aperture radar, Antelope Valley, Mojave Desert, California: Water Resources Research, v. 34, p. 2,573-2,585.

Ikehara, M.E., Galloway, D.L., Fielding, E., Bürgmann, R., Lewis, A.S., and Ahmadi, B., 1998, InSAR imagery reveals seasonal and longer-term land-surface elevation changes influenced by ground-water levels and fault alignment in Santa Clara Valley, California [abs.]: EOS (supplement) Transactions, American Geophysical Union, no. 45, November 10, 1998, p. F37.

Massonnet, D., Briole, P., and Arnaud, A., 1995, Deflation of Mount Etna monitored by spaceborne radar interferometry: Nature, v. 375, p. 567-570.

Massonnet, D., and Feigl, K.L., 1998, Radar interferometry and its application to changes in the earth's surface: Reviews of Geophysics, v. 36, p. 441-500.

Massonnet, D., Holzer, T., and Vadon, H., 1997, Land subsidence caused by the East Mesa geothermal field, California, observed using SAR interferometry: Geophysical Research Letters, v. 24, p. 901-904.

Massonnet, D., Rossi, M., Carmona, C., Adragna, F., Peltzer, G., Feigl, K., and Rabaute, T., 1993, The displacement field of the Landers earthquake mapped by radar interferometry: Nature, v. 364, p. 138-142. National Research Council, 1991, Mitigating losses from land subsidence in the United States: Washington, D. C., National Academy Press, 58 p.

Rosen, P.A., Hensley, S., Zebker, H.A., Webb, F.H., and Fielding, E., 1996, Surface deformation and coherence measurements of Kilauea volcano, Hawaii, from SIR-C radar interferometry: Journal of Geophysical Research, v. 101, p. $23,109-23,125$.

Vadon, H., and Sigmundsson, F., 1997, 1992-1995 crustal deformation at Mid-Atlantic ridge, SW Iceland, mapped by radar interferometry: Science, v. 275, p. 193-197.

Wicks, C. Jr., Thatcher, W., and Dzurisin, D., 1998, Migration of fluids beneath Yellowstone Caldera inferred from satellite radar interferometry: Science, v. 282, p. 458-462.

Zebker, H.A., Rosen, P.A., Goldstein, M., Gabriel, A., and Werner, C.L., 1994, On the derivation of coseismic displacement fields, using differential radar interferometry - The Landers earthquake: Journal of Geophysical Research, v. 99, p. 19,617-19,634.

For additional information contact: Devin Galloway (email: dlgallow@usgs.gov) U.S. Geological Survey

Placer Hall/California State University, Sacramento $6000 \mathrm{~J}$ Street

Sacramento, CA 95819-6129 